\title{
Design and Aesthetics of National Brand Clothing
}

\author{
Songli Yang \\ College of Fashion and Design, Donghua University, Shanghai 200051, China \\ Email: designerdamon@foxmail.com
}

\begin{abstract}
The design and aesthetics of national brand clothing is the key to national brand clothing going to the world. The aesthetics of national brand clothing combines practicality and artistry, and its design needs to abide by economic laws and humanistic laws, and it needs to reflect the aesthetic characteristics, color characteristics, pattern characteristics, decorative characteristics and Chinese elements of the national culture. The application of national traditional cultural symbols to the design of national costumes needs to highlight the national connotation of national costumes and carry forward the excellent ideological culture of national traditions.
\end{abstract}

Keywords: national, brand clothing, design, aesthetics

The differences between Chinese and Western cultures have made Chinese and Western countries have different perceptions of the beauty of clothing. Hegel compares clothing to architecture, and architecture can be compared to frozen music. Therefore, he believes that clothing has the beauty of rhythm and flow. Guo Moruo believes that clothing is a representation of ideology and culture. The Chinese believe that clothing has profound cultural connotations. The popular Hanfu and Tang suits in recent years are an example of this. Chinese national costumes are solemn, elegant, gorgeous and exquisite, and there are many kinds of them. Therefore, the technical elements of the existing products of clothing design have more aesthetic factors of artistic creation. Only when comfort and beauty are at the same time, clothing design and aesthetics can achieve perfect unity.

\section{The aesthetics of national brand clothing}

The evolution of clothing symbolizes the history of the development of human civilization. Human beings have gone from being undressed to the present, and the colorful and contending clothing has embodied the state of human economic and social development in a certain period of time. The national brand in clothing is the manifestation of a certain national culture. The aesthetic foundation of national brand clothing is Chinese traditional classical aesthetics. Chinese national clothing embodies the essence of traditional Chinese culture. In different historical periods, it is marked by the age and class, and records the passage of time and the vicissitudes of time. Aesthetics is the unique ability of socialized people ${ }^{[1]}$. Clothing aesthetics is the spiritual dependence and expression of human beings on clothing, reflecting the boundaries of a certain national culture, national psychology, fashion culture and popular trends. The aesthetics of clothing decorate the colors of the times. In the 1950s, my country's popular Lenin clothing, the 60s military casual clothes, the 70s and 80 s, the pointed collar shirts and bell bottom pants, after the 1990s, the clothing industry in our country has been innovative, inclusive, and full of flowers. Sheng-like. Clothing aesthetics originates from aesthetics in art philosophy, including literary aesthetics and technical aesthetics, expressing the aesthetic preferences, trends and aspirations of the times, highlighting people's lifestyle and civilization, and revealing the progressive state of human life. Human clothing has the practical function of keeping out the cold and heat, and the pleasant aesthetic function of beautifying life. Practical functions meet the needs of humans in real life, and aesthetic functions can meet the needs of human spiritual world for beauty.

National brand clothing needs to integrate aesthetics with practicality and integrate practicality with aesthetics. Both are two aspects of the same process and must be possessed at the same time. It is necessary to integrate elements of Chinese traditional excellent culture into aesthetics, inherit and carry forward the reasonable factors in traditional national costumes, and demonstrate the modern factors in the advanced socialist culture with Chinese characteristics. National brand clothing embodies the subjective spiritual activities of modern people. For example, the Chinese Lining brand clothing is a good demonstration of the Chinese image of the Chinese people and the country's rapid rise. The popularity of Hanfu and Tangzhuang in national brand clothing in modern life has better promoted our nation's aesthetic spirit and cultural taste. The publicity of brand clothing in commercial clothing display is compatible with the coexistence of aesthetic appreciation in cultural performances and art performances.

Take dress and suitability as the basis of aesthetic design. No matter how bright the colors and styles of clothing are, 
it must be adapted to the human body and coordinated with the expression of human spiritual temperament to form a fresh and vibrant national brand aesthetic object, and finally form a complete work. The clothing aesthetic judgment is highly anticipated. Therefore, the creation of any national clothing brand is inseparable from the initial stage test of clothing to test the adaptability of the work and then publicize it. It is worth noting that the aesthetic grasp of practical clothing and artistic clothing needs to find a balance between the two at any time. The mutual relationship is interaction, interdependence, and dialectical unity. This is the fundamental principle of national brand clothing aesthetics. The law embodies the ultimate ethical care of human creation. National brand clothing reflects the inheritance and innovation of human national cultural wisdom. Just like Zhao Wuling's "Hufu riding and shooting", it can adapt to the needs of the development of human society and promote the continuous advancement of human society. Chinese tunic suits instead of long gowns and jackets are an improvement from the Qing court in the Republic of China. National brand clothing is an organic combination of the metaphysical and aesthetic theory of the creation of utensils. The national brand standard is the carrier symbol of national culture in the sense of art and philosophy, which gives us national culture. Self-esteem and self-confidence are expressions of national emotions, individual vitality and hope.

\section{Design of national brand clothing}

"Fashion design is not only product design, but also artistic creation. It involves the beauty of function, the beauty of science, and the beauty of technology." ${ }^{[2]}$ National brand clothing design is a type of modern design. It must first satisfy the survival of human life. Needs are based on practicality; secondly, they must conform to human aesthetic standards and laws. The design of national brand clothing should reflect the characteristics of the times and at the same time reflect the nationality. Different from spiders forming webs and bees building nests, the national brand clothing design embodies the innovative wisdom of national culture. If it is just a mechanical copy of national culture, it will only be effective. The specific design work is the digestion, absorption and creative regeneration of human technological civilization. Under the conditions of a market economy, the design and development of clothing products belong to the upstream and top of the internal production system of the clothing industry, which is directly related to the economic benefits of clothing companies and the survival and development of the companies. Designers need to meet the demands of people's production, life and aesthetics. Design needs the influence of national ideology and culture and the innovation of artistic aesthetics. Designers need to learn from others, and need to have a profound cultural background and theoretical foundation. He is not copying and copying. "The first essence of the beauty of design is'new"' ${ }^{[3]}$, It is seeking newness, seeking difference, seeking beauty, seeking truth, seeking change. It can be an improvement change, or it can be a disruptive innovation and creation.

National brand clothing design needs to abide by the laws of economics and humanities. It needs to be designed according to the laws of the market. Winning the market and users must conform to the laws of economics, respect the laws of value, and be linked to corporate profits. Design needs humanistic and humanistic care, and ultimately serves the real life of mankind and realizes people's pursuit of truth, goodness and beauty. In terms of specific design, it is necessary to take into account the craftsmanship, material, fabric, technology, balance, shape, color, style, rhythm and movement of clothing. Human beings from naked to animal skins are the evolution of human beings from barbarism to civilization. Clothing is the incarnation of human civilization and progress. National brand clothing is the essence of national culture. The costumes of characters in Kunqu Opera and Peking Opera are even more important. The characterization of ancient Chinese culture, the Chinese nation has gone from wide-clothes, small hats, long robes, mandarins, cheongsams, tunic suits, and replaced suits and professional suits, which constitute the chain of the development of the Chinese nation's clothing culture. Cultural differences bring people's love and preference for specific clothing. Chinese people like Tang suits, Japanese people like kimonos, British people like to wear suits, and Americans like sportswear. This is the difference and difference of national culture. In addition to design, national brand clothing products need to be produced and sold to realize the designer's labor value. This is a broad design process, a social recognition process of product design, and a spiritual creation process of art design. And the production process of material means of subsistence. Designers, products, and customers constitute the elements of the art world of brand clothing, and play an important role in creating a better life for human beings and cultivating people's artistic sentiments. This is the life value and artistic value of national brand clothing design.

"National costume design contains cultural factors, revealing the language of the nation, and showing the cultural connotation of the nation" ${ }^{[4]}$. National brand clothing is not only a material product but also a spiritual and cultural product. Its design requires designers to have a good professional and cultural foundation, be able to master professional skills proficiently, have a deep understanding of Chinese traditional culture and Western culture, and be able to Through the concrete representation of clothing, the dazzling brilliance of national culture can be transformed. Such a design is the 
integration of professional skills and culture, as well as the externalization of national emotion and will. Only when such national brand clothing is created can it have the long-lasting artistic vitality and also This is so that designers can have a continuous source of creativity, and then create national costumes that are worthy of the nation and the times. Contrary to the aesthetics of western clothing, the design of Chinese national brand clothing requires that the color, shape and style conform to the Chinese cultural traditions and national habits. The symmetry, balance, neatness, color and pattern of Chinese national brand clothing are embedded in love, loyalty, and seclusion. With cultural elements such as China's entry into the WTO, governance, pastoral, landscape, and Zen, it can be said that national brand clothing is the abbreviation and living carrier of Chinese humanities.

The requirements of national brand clothing design are mainly reflected in the following aspects. (1) Aesthetic characteristics. Adhere to symmetry and balance, which are expressed in the shoulders, sleeves, placket, hem, patterns and other parts. In addition, special attention is paid to the overall proportion of clothing, such as ancient Chinese women's blouses and long skirts, especially the matching ratio of the Song and Ming dynasties with long skirts and skirts has reached a harmonious beauty. (2) Color characteristics. The traditional Chinese color system includes five colors: blue, white, yellow, red, and black, with obvious meanings and identity marks. Black represents the unknown sky, yellow means the land at dusk, black and yellow represent the sky and the earth, and imperial costumes express More. Yellow represents the color of the royal family, and red has the color of civilians. Chinese people especially love red. Red represents celebrations and celebrations. It is necessary to paste red couplets and red paper-cuts during the New Year, wear red clothes, and have a positive, enthusiastic, and upward rhythmic beauty. (3) Pattern features. Traditional Chinese clothing patterns are more concerned with the humanistic atmosphere and classical feelings contained in the clothing. Historical allegorical patterns, for example, "auspicious patterns" include pine, bamboo, and plum that symbolize the friends of Sui Han. (4) Decorative features. Such as the simple style of clothing in the Qin and Han Dynasties. (5) Chinese elements. Style elements include symmetry, balance and other elements; color elements include five colors: green, white, yellow, Zhu, and Xuan. Pattern elements include allegorical combinations of animal and plant patterns; decorative elements include inlaying, rolling, painting, embroidery and other decorative techniques.

\section{Traditional cultural symbols in national brand clothing}

The symbol in the semiotic school generally refers to the image that represents a specific meaning in the cognitive perspective of a specific context. The form of the symbol is rich and diverse. It can be expressed in graphics and images, or in sound and text. It can be expressed as a sculpture or a specific ideology and culture. It can be embodied in objects or spread by people. The scope of symbol application Extensive and rich in content. Traditional cultural symbols refer to images of ideology, ethics, philosophy, art, and systems that are in the same line, which are "the tie of national spirit" ${ }^{[5]}$. In a general sense, culture has symbols. Chinese traditional cultural symbols are roughly composed of two types: natural symbols and humanistic symbols. Natural symbols are represented by natural landscapes such as mountains and rivers; humanistic symbols are represented by ceramics, architecture, Tai Chi, medicine, calligraphy, and opera facial makeup. The application of traditional cultural symbols in national brand clothing is of great significance. It transmits the spiritual breath of national culture and expresses the thoughts of various nationalities.

The cultural implication and aesthetic interest of national brand clothing are conveyed through traditional cultural symbols. On the one hand, it highlights the national charm. The blending of modern clothing and traditional cultural symbols enables traditional cultural symbols to obtain an effective carrier, which in turn demonstrates the national character and folk customs of national brand clothing, and becomes a symbol of national culture. The etiquette costumes used in the 2008 Olympic Games combined blue and white porcelain, jade pendant, silk and other Chinese elements and symbols, showing the wisdom, tenderness, dignity and luxury of oriental women. On the other hand, it enhances the added value of business. Culture is the accumulation of human thought. It has specific stability and inheritance, and therefore has human edification and aesthetic value. The cultural factors in national brand clothing will undoubtedly increase its added value under market economy conditions. The cultural aesthetics of clothing fills the cultural gap of a single form of clothing, and satisfies human needs for truth, goodness, and beauty through traditional cultural elements and symbols, and makes people feel good and happy in the invisible and inadvertent. For example, my country's "national costume" - cheongsam can become one of the representatives of national costume culture, the reason is that it is deeply imprinted with national culture. The popular Tang suits in our country make Chinese people feel the roots of national culture and blood kinship wherever they go. The patterns of moiré, round flowers, and round life patterns, as well as the production techniques of jacquard, brocade, and embroidery, are all Is unique. The unique rhythm and style of national brand clothing needs the embellishment of traditional cultural symbols. It is also the traditional cultural symbols that make our national 
brand clothing colorful and fascinating.

\section{The future of national brand clothing}

The popularization of science and technology in the world today has opened up unlimited possibilities for the development of national brand clothing. There is still a long way for my country's local national brand clothing to go to the world and to the world clothing stage. Although our country is a big country in clothing, it is not yet a strong country in clothing. We need to vigorously explore national wisdom and boldly innovate. We will definitely be able to create a new world of our own national clothing.

Only a nation can become a world. First of all, we must increase scientific research. It is necessary to strengthen the professional construction of clothing design, not only to increase the learning of professional skills and knowledge, but also to fully explore the aesthetic characteristics and knowledge elements of the national clothing culture through the systematic learning of Chinese and Western traditional cultures, enhance the national character of clothing design and aesthetics, and The national culture is combined with the requirements of the times, while at the same time absorbing the advantages of Chinese and Western clothing culture, and constantly innovating the shape of clothing. We should not stick to the ethnic elements in traditional culture, but should find the best balance between fashion and the market, and rationally integrate ethnic culture with fashion and the market to create a strong ethnic style and fashion. Trendy brand clothing must break the "Western-centrism" ideology. With the growth of my country's economic strength and the improvement of technological level, my country's national brand clothing will take a broad road. Second, vigorously cultivate designers in practice. The training of designers depends on the industry to support them. Designers must not only be professional but also have a profound cultural background, in order to design good works for national brand clothing. In other words, the designer's aesthetic vision and professional skills are the key to the growth and development of national clothing brands. "Rose Fang", "Wuyou" and Lawrence Xu's dresses are all brands cultivated in practice, and they have a higher reputation in China. The popularity and brand reputation of the company. Third, we must strive for government support, establish cultural self-confidence, and increase brand influence. Major government events have an irreplaceable role in the promotion of national brand clothing. Similarly, international film festivals, film and television and other international cultural platforms play a greater role in the expansion of national brand clothing to the world. We must actively encourage domestic national brand works to participate in more The world's clothing display is progressing in learning, exploration and comparison. Finally, we must play the role of modern media means. In 2013, "Liyuan style" swept the world with Peng Liyuan's visit. The elegance, generosity and beauty of its Chinese style have been favored by domestic and foreign media. The intellectual and self-confidence of Chinese women are fully revealed. This provides a world recognition stage for Chinese national brand clothing.

\section{Conclusion}

The globalization of Chinese national brand clothing must be guided by the concept of national culture, based on brand building, "make use of the successful experience of world-renowned brands to achieve brand internationalization" ${ }^{[6]}$, identify the product structure and category, and develop high-end, Individualized, nationalized, fashionable, popular, functionalized, high-quality, high-performance and high-quality products, on the basis of satisfying people's daily life, adapting to people's pursuit of beauty, promoting traditional Chinese culture to go abroad, enhancing national cultural confidence, and delivering The voice of China enhances the global discourse power and competitiveness of national brand clothing, so that the Chinese national brand clothing will eventually become brilliant in the innovation and development, and continue to write the beautiful chapter of the revival of the Chinese nation.

Acknowledgments

This article is one of the phased achievements of the Jiangsu Provincial Social Science Fund Project "Research on Identity Education of Socialist Core Values in Colleges and Universities in the New Media Era" (19MLD002).

\section{References}

[1] Mai Jian. Thoughts on the social factors that determine the aesthetic standards of clothing. Art Education. 2019; (11): 189.

[2] Ban Ting. Some thoughts on the aesthetic meaning of clothing. Journal of Liaoning Institute of Science and Technology. 2012; 14(03): 98 . 
[3] Chen Geng, He Xiaoyan. A Brief Talk on Design Aesthetics and Clothing Aesthetics. Art and Design (Theory). 2011; 2(01): 27.

[4] Peng Hui. The cultural and aesthetic characteristics of national costume design. Guangdong Sericulture. 2019; 53(03): 110.

[5] Bai Yue, Qiao Jimin. Research on the application of traditional cultural symbols in the display and design of national costumes. Modern Decoration (Theory). 2015; (07): 131.

[6] Zhang Junlang. Exploration of the internationalization of the development of Chinese national clothing brands. International Textile Herald. 2020; 48(04): 55. 